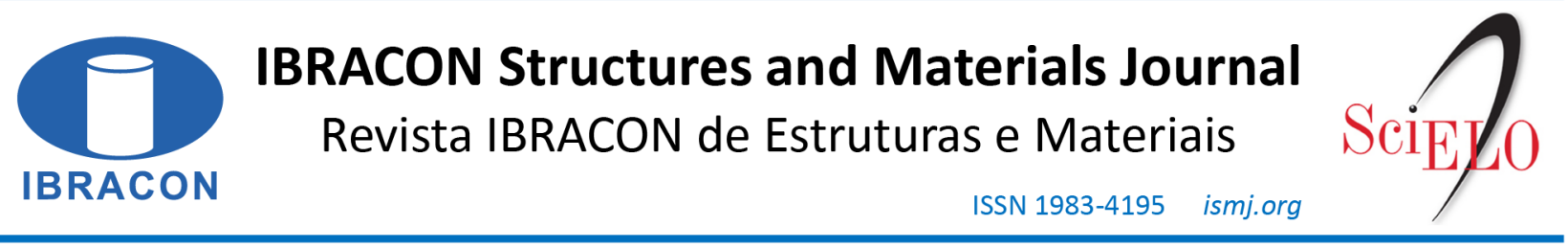

ORIGINAL ARTICLE

\title{
Monolithic equivalent stiffness of precast columns with grouted splice sleeve connections
}

\section{Equivalência monolítica de rigidez em pilares pré-moldados com emendas com luvas grauteadas}

\author{
Marcelo de Araujo Ferreira ${ }^{a}$ \\ Luís Augusto Bachega ${ }^{\mathrm{a}}$ (D) \\ Bruna Catoia ${ }^{\mathrm{a}}$ (D)
}

${ }^{a}$ Universidade Federal de São Carlos - UFSCar, Departamento de Engenharia Civil, São Paulo, Brasil

Received 24 October 2019

Accepted 23 April 2020

\begin{abstract}
The aim of this paper is the validation of monolithic equivalent stiffness applied to precast columns with grouted splice sleeve connections, wherein spliced precast elements have been compared with continuous monolithic elements. The experimental investigation has been carried out with bending tests for two spliced elements (L1 and L2), comparing the deflections along these elements with the results obtained from two monolithic elements (M1 and M2). The grouted splice sleeve connections have been characterized by their rotational stiffness (moment-rotation relationship), ultimate strength, and ductility, allowing the calibration of the equation for the secant stiffness according to ABNT NBR9062:2017. Based on the experimental results, the effective deformation length within the connection zone obtained was $\mathrm{L}_{\mathrm{ed}}=20 \phi$, corresponding to a secant stiffness of $R_{\text {sec }}=77,785 \mathrm{kN} \cdot \mathrm{m} / \mathrm{rad}$. Although relative rotations have been observed at the grouted splice joint, the deflections along the precast spliced elements were very close to the deflections along the monolithic elements. A strong convergence for all phases of the load $\mathrm{x}$ displacement curves has been observed, as well as good approximation in terms of rotational stiffness, strength and ductility. Therefore, based on the analysis of the experimental results, the requirement to define the monolithic equivalent stiffness for the precast columns has been met.
\end{abstract}

Keywords: precast concrete structures, equivalent connection, monolithic, secant stiffness.

Resumo: O propósito deste trabalho é a verificação da equivalência monolítica de rigidez de pilares prémoldados com emendas por meio de luvas mecânicas grauteadas, onde os deslocamentos ao longo de protótipos pré-moldados segmentados foram comparados com deslocamentos obtidos ao longo de protótipos monolíticos contínuos. Para tal, realizou-se um estudo experimental com ensaios de flexão simples para modelos pré-moldados com ligações (L1 e L2), cujos resultados experimentais foram comparados com os resultados de ensaios em modelos monolíticos contínuos (M1 e M2). Adicionalmente, as ligações por meio de luvas grauteadas foram caracterizadas quanto à sua rigidez (relação momento-rotação), resistência e ductilidade, possibilitando a calibração da equação da rigidez secante para relação momento-rotação definida na ABNT NBR9062:2017. O comprimento efetivo de deformação da barra tracionada na região da junta atingiu um valor médio de $\mathrm{L}_{\mathrm{ed}}=20 \phi$, correspondente a uma rigidez média de $\mathrm{R}_{\mathrm{sec}}=77,785 \mathrm{kN} \cdot \mathrm{m} / \mathrm{rad}$. Com base na comparação experimental entre os modelos com ligações e os modelos monolíticos, observou-se que embora tenha havido uma descontinuidade na região da junta grauteada, com liberação de rotações relativas entre os elementos de pilares pré-moldados, os deslocamentos apresentados ao longo dos protótipos segmentados foram muito próximos aos deslocamentos obtidos nos elementos monolíticos, tendo-se uma boa convergência para todas as fases da curva força x deslocamento, com equivalência de rigidez, resistência e ductilidade para as curvas analisadas, caracterizando-se assim a equivalência monolítica do pilar pré-moldado.

Palavras-chave: estruturas pré-moldadas, ligação equivalente, monolitismo, rigidez secante.

How to cite: M. A. Ferreira, L. A. Bachega, and B. Catoia, "Monolithic equivalence of precast columns with grouted splice sleeve connections," Rev. IBRACON Estrut. Mater., vol. 14, no. 1, e14115, 2021, https://doi.org/10.1590/S1983-41952021000100015

Corresponding author: Bruna Catoia. E-mail: bcatoia@yahoo.com.br

Financial support: Leonardi Industrialized Construction Company and Splice-Sleeve Japan.

Conflict of interest: Nothing to declare. 


\section{INTRODUCTION}

In addition to the influence of the semirigid behavior of beam-column connections, lateral sway in precast structures is highly affected by the actual stiffness of the precast columns, which is also affected by premature cracking during the transitory phases of production and during the assembly of structural precast members, as well as affected by crack formation within the serviceability limit state.

Column connections can be positioned either at the bottom or at mid-height of the column, which is the case in multistory buildings. For precast columns consisting of spliced members, the actual lateral stiffness of the whole column can be affected by relative displacements within the joints, either at the mid-height column-to-column joint or at the bottom of column-to-foundation joints. As such, these localized deformations in the joints will increase the lateral sway of the building, especially in industrial buildings with cantilevered columns. Figure 1 shows typical solutions of column-to-column connections used in Brazil.

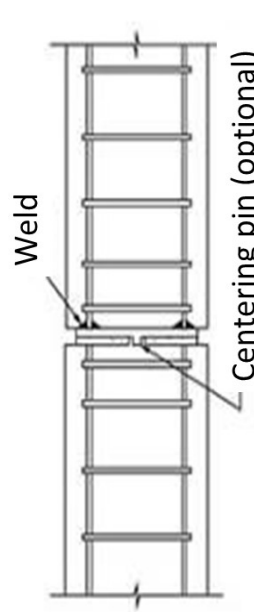

a) Connection with a welded plate

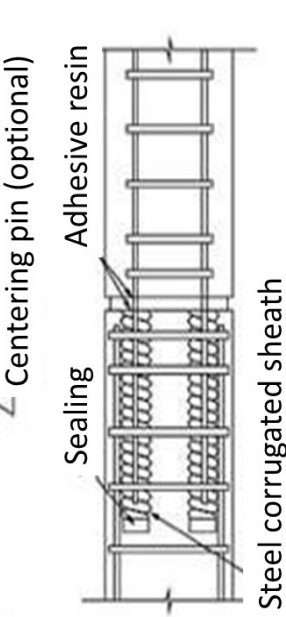

b) Connection with a bottom projecting reinforcement

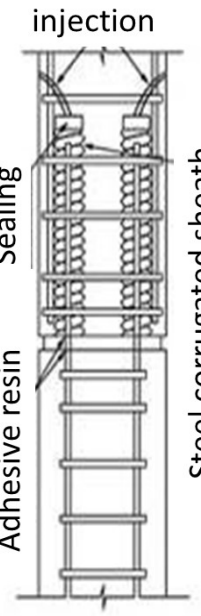

c) Connection with a top projecting reinforcement

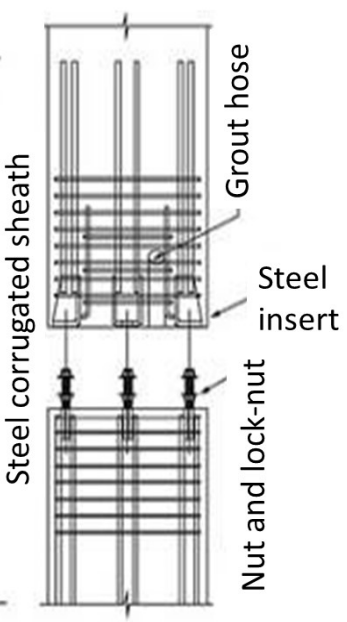

d) Connection

with a steel

device

Figure 1. Typical column-to-column connections according to ABNT NBR 9062:2017 [1].

Depending on the moment-rotation relationship of a column-to-column connection, which characterizes its semirigid behavior, spliced precast columns can behave as continuous or discontinuous columns (equivalent monolithic columns). Therefore, for multistory buildings, with joints at mid-height of the columns, the structural continuity of precast columns is highly dependent on the connection behavior itself.

The existing studies on columns with grouted splice sleeves are mostly addressed to the structural behavior in seismic zones, wherein the main research interest is related to the ultimate plastic strength and ductility of the rebars crossing the joints. However, there is no monitoring of the moment-rotation relationship in the joints, which is needed to determine the secant rotational stiffness of the connections according to [1].

\subsection{Scope}

The aim of this paper is the hypothesis verification of the monolithic equivalence applied to precast columns with grouted splice sleeve connectors. An experimental investigation with four bending tests has been conducted for two spliced models (L1 and L2), wherein the deflection along these models were confronted against the results obtained from two monolithic models (M1 and M2). Additionally, the grouted splice sleeve connections have been experimentally characterized by their stiffness (moment-rotation relationship), strength and ductility. Therefore, the level of restriction in the relative displacements between the connected elements within the precast models could be evaluated. 
According to ABNT NBR 9062:2017 [1], it is possible to use any building technology for precast structures based on demonstrated performance with conclusive tests in order to evaluate the connections as specified in the design. On the other hand, designers cannot rely on technologies with demonstrated performance based on tests carried out in other countries, without considering local conditions for materials and production processes applied in Brazil.

Column-to-column connectors comprising mechanical sleeves filled with grout are widely used in Brazil. However, grouted splice sleeves require shorter anchorage lengths, it is very important to study the actual anchorage performance of the bars as well as the efficiency of the high strength grout that is used to fill the splice sleeve.

\section{LITERATURE REVIEW}

\subsection{Previous research}

Einea et al. [2] investigated the effect of confinement on the bond strength between the rebar and the surrounding grout within mechanical sleeves. Grout-filled steel sleeves with different parameters and geometrical design were loaded for axial tension until failure. The experimental results were discussed and analysed in the light of the design criteria based on tensile strength and ductility. The results strongly indicate that precast members can be safely connected when using standard steel sleeves filled with field grout. The investigation focused on a typical splice sleeve that was capable of developing a minimum strength of $125 \%$ of the bar's yield strength with the potential of reaching the ultimate strength of the bar.

The research presented in Ahn et al. [3] also had the purpose of studying the effect of confinement on the bond strength between the rebar and the surrounding grout within the mechanical sleeves. A total of 6 full-scale prototypes were tested under monotonic loads, using strain gauges at 12 locations within the sleeve and along the reinforcing bar. The experimental variables were the embedment length and the diameter of reinforcing bars. Ahn et al. [3] concluded that under the ultimate strength condition, the confining pressure within the grouted splice sleeve improved the connector performance, allowing a reduction of the embedment length of the reinforcing bar.

In Hua et al. [4], 35 specimens were tested under incremental tensile force. These specimens varied in terms of configurations and were assessed for feasibility in the aspects of bond strength, ductility response and failure modes. According to Hua et al. [4], the typical modes of failure were bar tensile failure, grout-bar bond failure, grout-sleeve bond failure, and sleeve tensile failure. These failures revealed the parameters to be considered in the design of a splice connector. Hua et al. [4] concluded that under confinement, the required anchorage length of the bars can be shortened to nearly nine times the diameter of the spliced bar.

In addition to the studies on related to the maximum capacity of grouted splice sleeves, the major concern regarding this connection, especially in countries such as the USA and Japan, is related to the guarantee of high ductility, wherein the studied connection should be able to absorb deformations without failure when subjected to seismic actions. Thus, many column-to-column connections have been studied with the purpose to act as assembly connections or as connections with sufficient ductility required to resist against seismic actions.

Belleri \& Riva [5] investigated the suitability of grouted sleeve connections as column-to-foundation connections for precast concrete structures in seismic regions. Experiments on the cyclic behavior of column-to-foundation subassemblies compared the response of grouted sleeve connections with cast-in-place and pocket-foundation connections. The results demonstrated that grouted sleeves ensure a ductility and energy dissipation capacity similar to those of traditional connections. According to Belleri \& Riva [5], the confinement provided by the grouted sleeves inhibits buckling of the longitudinal reinforcement and increases the compressive strength of the grout. As a consequence, the damage associated with this kind of connection is localized to the column base, allowing easier postseismic column repair compared to traditional connections.

Ameli et al. [6] investigated the seismic performance of grouted splice sleeve connections with the connectors placed in the column or footing of bridge subassemblies and intentional debonding of the footing dowel bars. In this research, quasi-static cyclic loads were used to test three half-scale precast column-to-footing specimens and one castin-place control specimen. The precast concrete specimens incorporated grouted splice sleeve connectors in which two bars were grouted at both ends. According to Ameli et al. [6], experimental results showed that the precast subassemblies had lower ductility capacity than the control cast-in-place specimen. On the other hand, an improved seismic response was observed when the splice sleeve connectors were located inside the footing rather than the column end. An intentional debonded reinforcing bar zone was used to further improve the displacement ductility capacity of the assembly. 
Kinnunen [7] presents the results of tests carried out for precast column connections with column shoes and anchor bolts. There were 24 precast column connections tested with different column dimensions and different types of column shoes for bending resistance, rotational stiffness, shear capacity and fire resistance. The experimental results have confirmed that the stiffness of the column-to-column connection is at least as rigid as a continuously reinforced castin-situ column connection.

Kinnunen [7] presented a test set up corresponding to a four-point bending test who is the aim was to verify the design rules of EN 19921-1 [8], recommended for slender cast-in-situ columns. In this particular case, the equivalent stiffness of the precast unit was measured without any axial force in order to have a conservative evaluation. Figure 2 illustrates the different zones for relative flexural stiffness in precast and cast-in-situ columns.

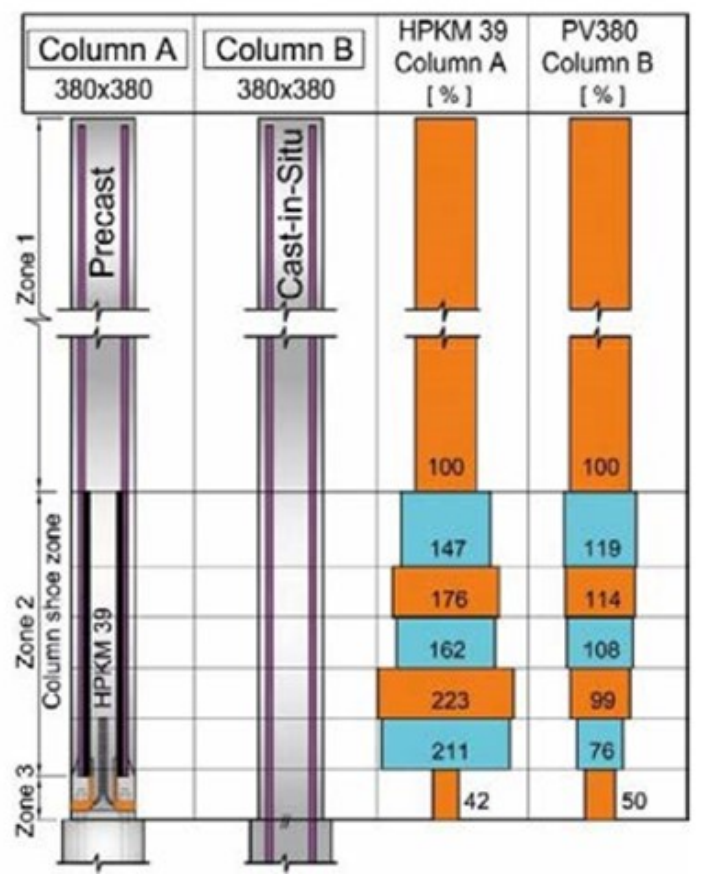

Figure 2. Relative bending stiffness of subzones (Kinnunen [7]).

The precast column A was compared with a reference column B, which was cast-in-situ and continuously reinforced with the same main longitudinal reinforcement as for the precast column. According to Kinnunen [7], the intention in this research was to compare the stiffness of a precast column with that of the reference column. In Zone 1 of the precast column A, the column shoes did not affect the column stiffness. In Zone 2, the flexural stiffness was very high due to the overlapping of the anchor bars of the column shoes and the main reinforcement of the column. In Zone 3, the flexural stiffness was quite low due to the reduction of the effective concrete section at the end of the column with an eccentric tensile force in the column shoes. Based on the experimental results, Kinnunen [7] concluded that the relative stiffness of precast column A and cast-in-situ column B in Zone 1 were naturally the same. In Zone 2, and especially in its lowest subzone, the relative stiffness of precast column A was significantly higher $(229 \%$ and $211 \%)$ than that of the cast-in-situ column B (102\% and 76\%). The relative stiffness of the cast-in-place column B and its zone 3 was lower than zone 2. The relative stiffness of the column shoe connection in zone 3 was lower than in upper zone 2. Although the relative stiffness of zone 3 of the precast column A was lower than that of the cast-in-situ column B, the difference was minor. When compared with column B, the higher stiffness in zone 2 of column A will compensate for the lower stiffness in zone 3. The calculated deflections at the top of the columns were $380.7 \mathrm{~mm}$ and $450.2 \mathrm{~mm}$ for HPKM 39 and PV380, respectively. Thus, the column A with column shoes was stiffer than the column B and the tests confirmed that the connection with a grouted joint between the precast column and base structure behaves in the same way as a corresponding monolithic reinforced cast-in-place column.

Tullini and Minghini [9] present the results of full-scale tests on precast reinforced concrete column-to-column connections made with grouted sleeve splices. The precast column units had a square cross-section of $500 \mathrm{~mm}$ wide. 
Eight bars with $20 \mathrm{~mm}$ diameter protruding from one unit were grouted into corrugated steel sleeves encased in the other unit. The column-to-column connections were subjected to three monotonic tests (axial tension and four-point bending with and without axial compression) and two cyclic tests (four-point bending and shear). According to Tullini and Minghini [9], the tension test failure took place far from the interface between the precast units and highlighted the effectiveness of the stress transfer along the splice region. Tullini and Minghini [9] showed that in all other tests, damage developed at the interface between the precast units, the rotation that concentrated at the interface led to a moderate reduction of the global bending stiffness. In the case of the shear test, the pure shear capacity of the bars crossing the joint was achieved. Furthermore, the cyclic bending test resulted in a ductile and stable hysteretic behavior in the connection.

Although grouted sleeves have been widely studied in the international literature, all these studies focused on the evaluation of the strength and ductility of the connections, while considering their application in the seismic regions such as the United States and Japan. However, the information that allows one to evaluate the secant stiffness of connections to be considered in the stability analysis has not been fully addressed within the technical literature.

In this context, this paper contributes to the improvement of practical design applications of precast columns in Brazil, addressing new recommendations in ABNT NBR 9062:2017 [1], regarding strength, stiffness and ductility in column-to-column connections based on the research carried out by Bachega [10], wherein the behavior of this connection with grouted splice sleeves was studied, concerning the performance characterization of the relative stiffness of the precast spliced column. According to Bachega [10], special attention was given to the behavior within the column-to-column interface after cracking, to identify a possible occurrence of bond-slip between grout and steel bars prior but close to the yielding while considering the secant rotational stiffness of moment-rotation relationship according to ABNT NBR 9062:2017 [1]. Figure 3 presents a schematic layout of the grouted steel sleeve used in this paper (Splice Sleeve System) [11]. This paper presents the experimental results from a $\mathrm{PhD}$ research carried out by Bachega [10].

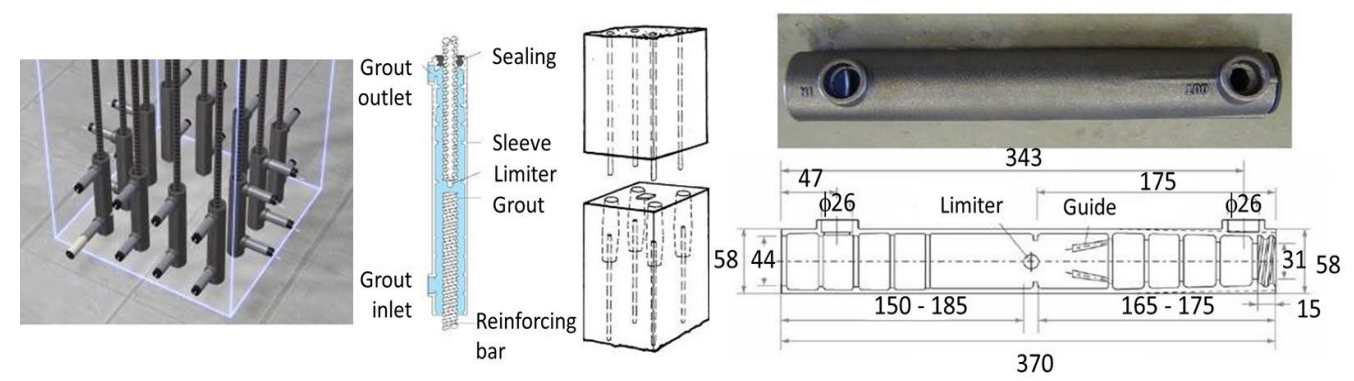

Figure 3. Grouted splice sleeve according to Splice Sleeve Japan [11].

\subsection{Monolithic equivalence of precast columns}

Since the studied connection was originally developed to be applied in buildings in seismic zones, most of the previous experimental studies limited their focus on the structural behavior of the connections related to their ultimate plastic strength and ductility (wherein the plastic rotational stiffness is given by $R_{\text {plast }}=M_{u} / \theta_{u}$ ). Therefore, in most cases, there was no interest of studying the rotational stiffness for the column-to-column connection within the serviceability limit state (after crack begins but before the steel bars start yielding).

According to the design criteria for structures in seismic zones recommended by ACI Committee 550 [12], applying the so called Emulative Design, precast elements can emulate the behavior of monolithic elements in design provided that their connections are capable to achieve the ultimate strength and ductility (plastic deformation higher than 2.5 times the yielding deformation), wherein the concept of Emulative Design is restricted to the emulation in terms of ductility. On the other hand, the concept of the monolithic equivalent stiffness comprises the monolithic emulation for all stages of the force-displacement relationship along the precast members. For the stability analysis of precast structures in non-seismic regions, it is essential to know the secant stiffness of the moment-rotation relationship of the connections in order to proper evaluate the lateral stiffness of the precast structure. In addition, it is also important to know the rotational stiffness of the connection within the serviceability limit state in order to obtain the effective 
stiffness of a spliced precast column, in order to decide if there is equivalence with the relative stiffness of a monolithic element.

According to Bachega [10], a precast column can be considered equivalent to a monolithic column if the criteria described hereafter is met:

- When lateral deflections (sideways) in the precast columns do not exceed $10 \%$ of the displacements in the equivalent monolithic columns.

- When the connection behaves as rigid (fixity factor $\alpha_{R} \geq 0.85$ ), the presence of the connection does not affect the continuous behavior of the precast column.

In order to characterize the structural behavior of a connection in a precast column, which is related to its rotational stiffness, flexural strength and ductility, Bachega [10] proposed a procedure that comprises a trilinear diagram based on the limit moment $\left(\mathrm{M}_{\mathrm{y}, \mathrm{lim}}\right)$ and the secant stiffness $\left(\mathrm{R}_{\mathrm{sec}}\right)$, as presented in Figure 4 and comprising Equations of 1 to 9.

$$
\begin{aligned}
& R_{\text {sec }}=\frac{M_{y, l i m}}{\theta_{y, \text { lim }}} \\
& R_{\text {ini }}=1.5 R_{\text {sec }} \\
& R_{u}=0.4 R_{\text {sec }} \\
& M_{y, l i m}=0.9 f_{y k} A_{s} d \\
& M_{\text {ini }}=0.5 M_{y, l i m} \\
& M_{u}=1.1 M_{y, l i m} \\
& \theta_{u}=2.5 \theta_{y, l i m} \\
& \alpha_{R}=\left[1+\frac{3(E I)_{e f}}{R_{\text {sec }} L}\right]^{-1}
\end{aligned}
$$

Considering the simplified equation proposed by Ferreira et al. [13] and adopted in [1].

$$
R_{s e c}=k \frac{E_{s} A_{s} d^{2}}{L_{e d}}
$$

Therefore, the effective deformation length can be directly determined from experimental secant stiffness by the following Equation 10.

$$
L_{e d}=k \frac{E_{s} A_{s} d^{2}}{R_{\text {sec }}}
$$


where $R_{\text {sec }}=$ secant stiffness; $M_{y, \text { lim }}=$ bending moment at the start of yielding of the flexural bar; $\theta_{y, l i m}=$ rotation in the start of yielding of the flexural bar; $R_{i n i}=$ initial stiffness (it refers to the serviceability limit state); $R_{u}=$ ultimate stiffness (plastic stiffness, it refers to the ultimate limit state); $k=$ coefficient of adjustment that varies between 0.75 to $1.0 ; L_{e d}=$ deformation effective length of the flexural bar; $M_{i n i}=$ initial moment (it refers to the serviceability limit state); $M_{u}=$ ultimate moment (plastic moment, it refers to the ultimate limit state); $\theta_{u}=$ ultimate rotation (plastic rotation, it refers to the ultimate limit state) $d=$ effective height of the effective cross-section; $A_{s}=$ the cross-sectional area of the steel longitudinal bar; $E_{s}=$ steel elastic modulus; $f_{y k}=$ characteristic yielding tension strength of steel; $\alpha_{R}=$ fixity factor of connections; $(E I)_{e f}=$ effective stiffness coefficient of the element.

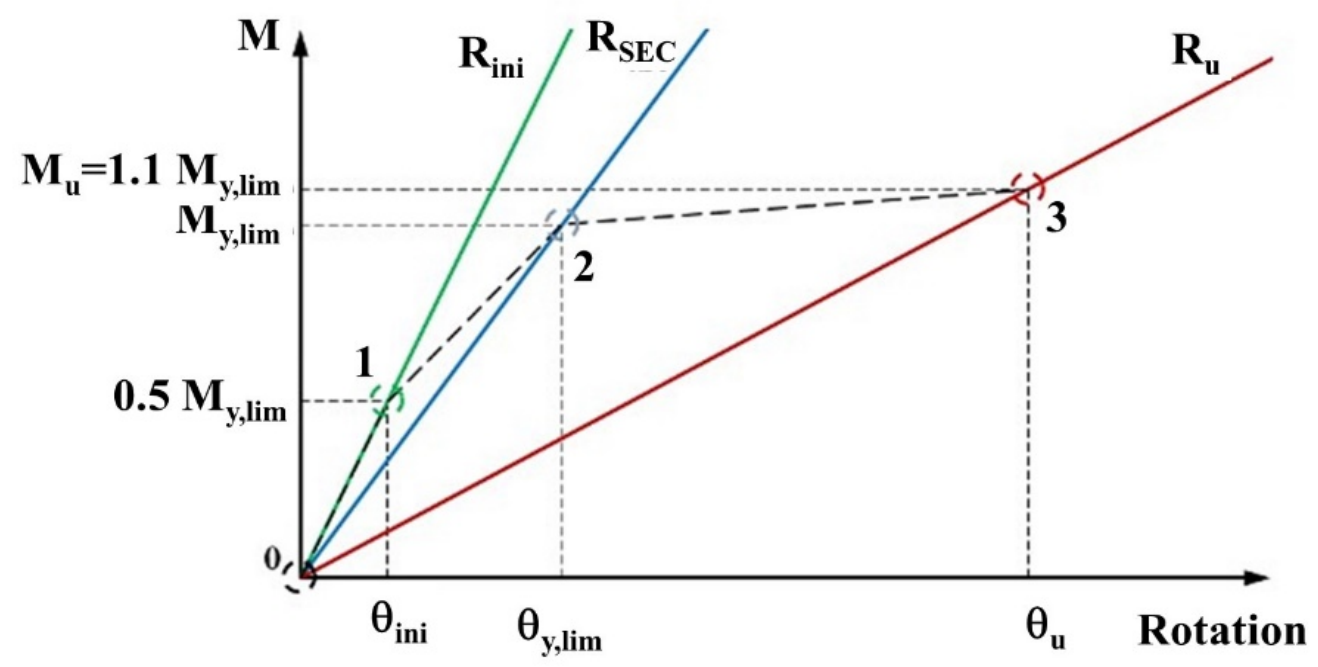

Figure 4. The proposed trilinear diagram in [10] for the characterization of the Monolithic equivalent behavior of precast jointed elements

The curve stretch $0-1$ is related to the initial deformation connector at the Serviceability Limit State (SLS) for bending moments lower than the limit given by $0.5 \mathrm{M}_{\mathrm{y}, \mathrm{lim}}$. The curve stretch $1-2$ is related to the design combination considered in the global stability analysis of the precast structures. In the case of precast structures, the consideration of connection secant stiffness aims to take into account the effects of cracking adding possible bond slippage within the connection region until prior the yielding of the steel bars. For the stretch 1-2, the secant stiffness represents the minimum rotational stiffness, wherein the design criteria of strength-stiffness is considered. For the last curve stretch, after the steel bars start yielding, the criteria design of strength-ductility is then considered. Therefore, the secant rotational stiffness of the connection is considered within the SLS.

\section{EXPERIMENTAL INVESTIGATION}

The experimental study carried out in Bachega [10] was intended to verify if a precast column with the studied grouted splice sleeve connector can be considered to possess equivalent stiffness of a monolithic column. The experimental investigation included four full-scale bending tests, with two specimens comprising monolithic elements (M1 and M2) and two models comprising of spliced columns with grouted splice sleeve connections (L1 and L2). The studied connection was also characterized in terms of rotational stiffness, flexural strength and ductility. Furthermore, the experimental results were used for adjustment of analytical models to represent the connection behavior according to the design criteria. It is worth mentioning that the simple bending test set up showed in Figure 5 does not apply any axial compression force on the column unit. Nevertheless, in the case of industrial buildings columns (cantilever posts), it is common to have a design combination of loads that leads to high bending moments at the base with low values for the axial compressive forces. As such, most precast industrial columns are designed as cantilever beams. Therefore, the four-point bending tests represent a good approximation for the behavior of a precast industrial building column (acting 
as a post). The connection studied in this research, showed in Figure 3, can be applied for different types of precast concrete elements when full continuity is required, including column-to-column, column-to-foundation and beam-to-beam.
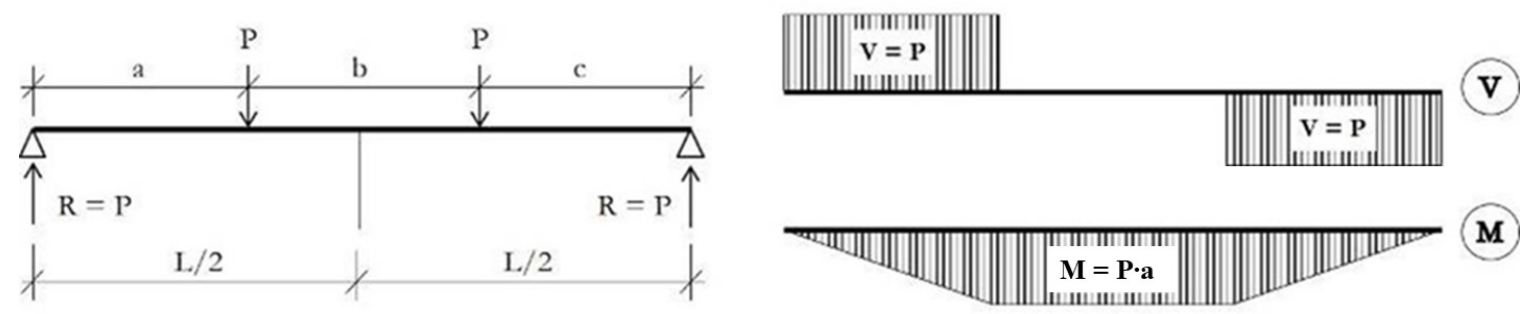

Figure 5. The structural layout of the four points bending test with bending moment (M) and shear force (V) diagrams.

\subsection{Design Model}

As previously said, two monolithic models (named M1 and M2, Figure 6) were used as a reference for comparison and verification of Monolithic equivalence of two models with grouted splice sleeve (named L1 and L2).

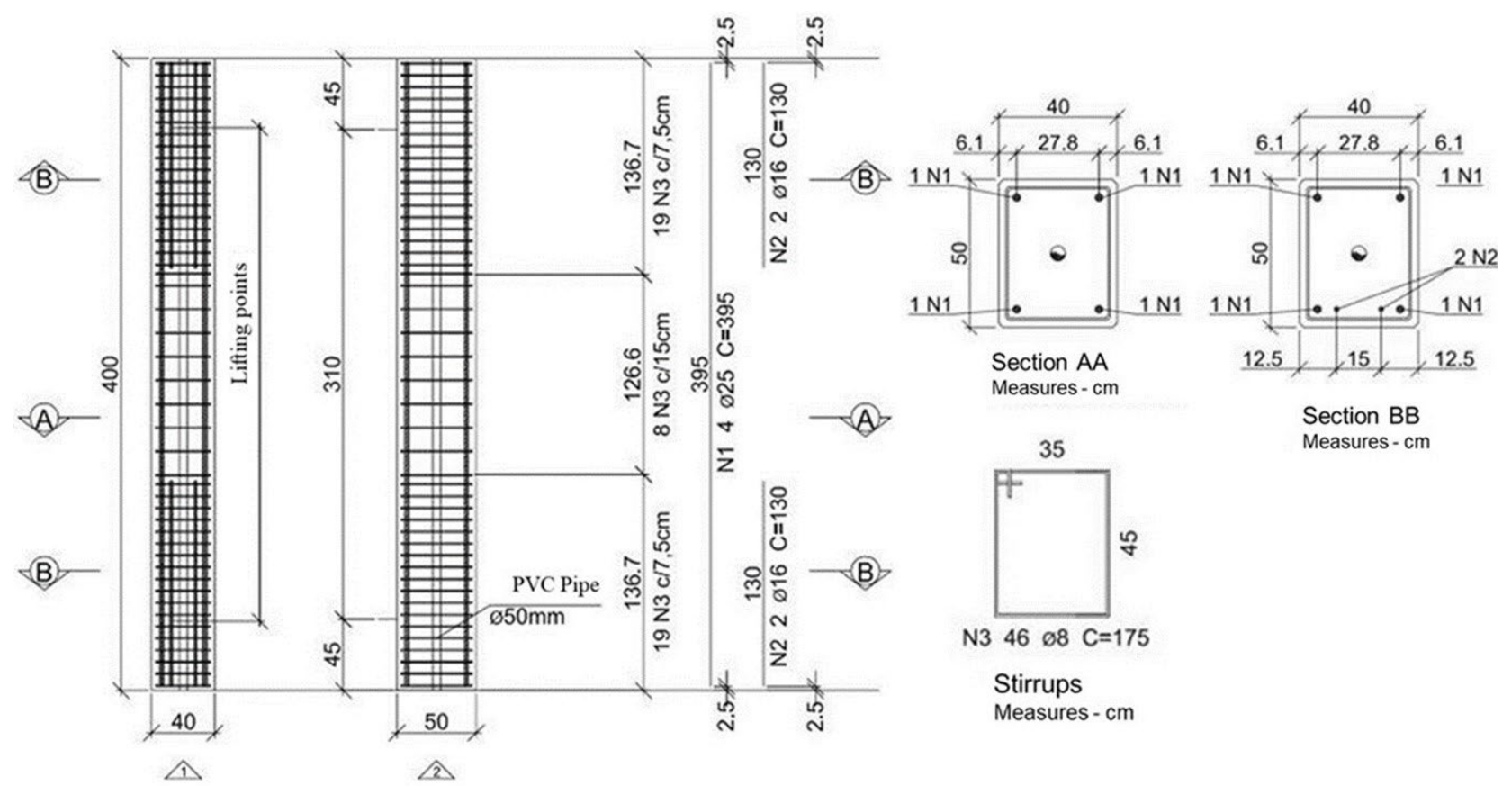

Figure 6. Design of the monolithic models (M) [10].

The dimensions of precast elements and the longitudinal bars were defined according to the maximum hydraulic actuator capacity of the laboratory NETPre, resulting in elements with a width of $40 \mathrm{~cm}$ and a height of $50 \mathrm{~cm}$ and with two longitudinal bars with a $25 \mathrm{~mm}$ diameter.

In the case of M models, the column elements were cast as a single element and in the case of L models (with connection), the elements were cast in two parts (Figure 7 and 8 ). 


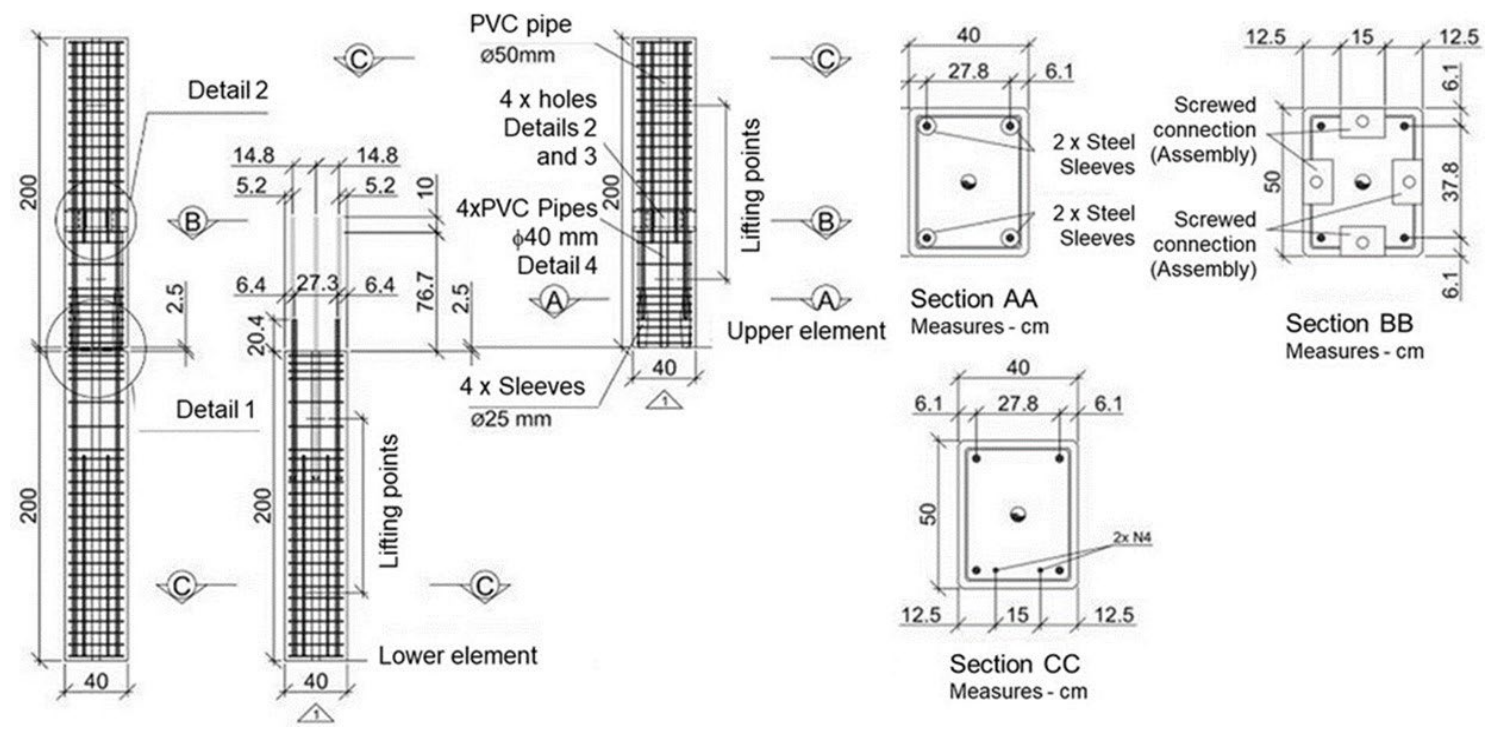

Figure 7. Design of the models with connections (L) [10].
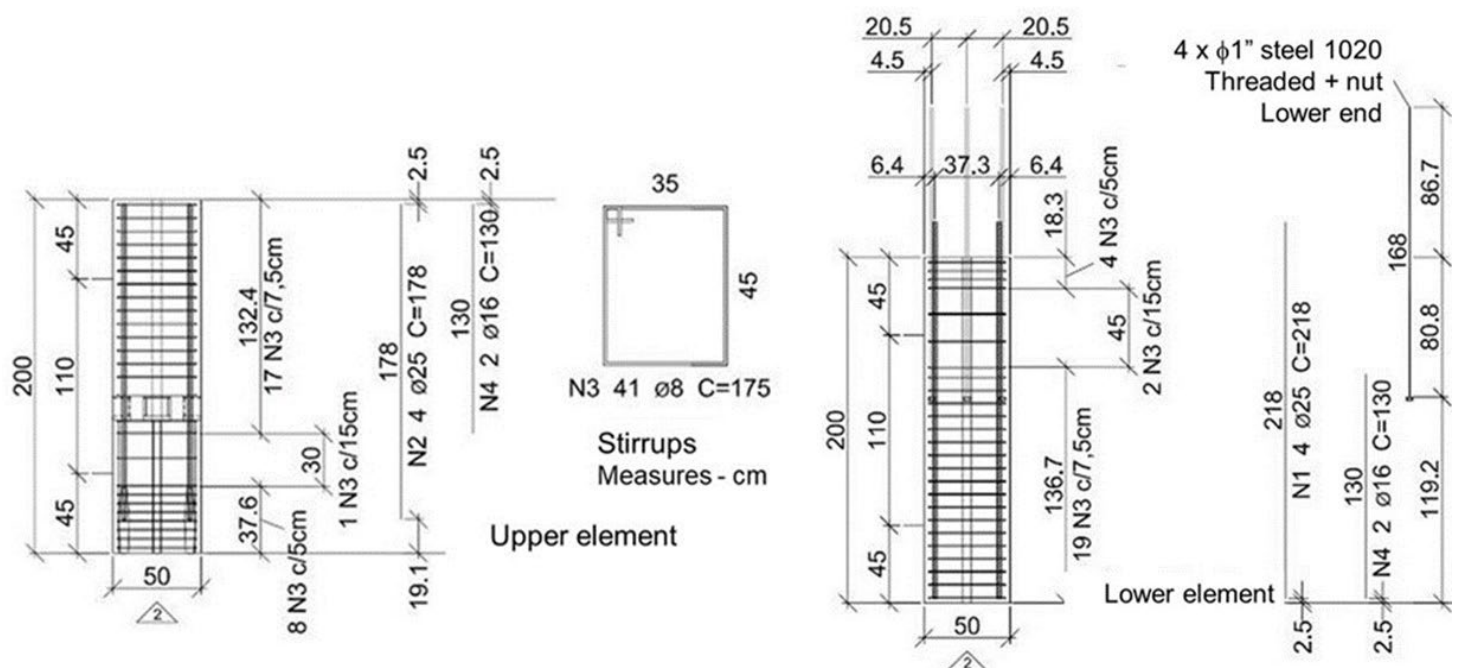

Figure 8. Detailing of the precast elements with connections (model L) [10].

All elements were prefabricated using steel molds at the Leonardi Industrialized Construction Company that donated all models to be tested.

The two monolithic elements were commonly cast because they had no specific details for their prefabrication. So, each monolithic element is $4 \mathrm{~m}$ in length. It is important to emphasize the concentration of stirrups at the end of the elements to control cracking in this region, inducing the failure to happen within the joint. Self-compacting concrete (SCC) with a compressive strength of $50 \mathrm{MPa}$ has been used. Furthermore, complementary bars (16 mm of diameter) were placed at one of the $400 \mathrm{~mm}$ faces with the dual purpose of strengthening this region while increasing the probability of failure at the central region.

Special care was taken for casting the elements with connections. The main difference between the $\mathrm{M}$ and $\mathrm{L}$ models was that, in L, there were two separate elements connected with grouted splice sleeves. In this case (L), each unit presented a length of $2 \mathrm{~m}$ plus a joint thickness of $25 \mathrm{~mm}$ that corresponded to $1 \%$ less than the length of the model M. It was considered that all the models had the same length, ignoring this small difference. Bars with a diameter of $25 \mathrm{~mm}$ were also used in each edge of the $2 \mathrm{~m}$ units but with different lengths: bars with a length of $2.18 \mathrm{~m}$ for the lower element (a length of $2 \mathrm{~m}$ for the element plus the bonding length of reinforcing bars within the grouted sleeves plus the joint length of $25 \mathrm{~mm}$, resulting in bar lengths of $2.18 \mathrm{~m}$ ) bars with a length of $1.78 \mathrm{~m}$ for the upper element (a length of $2 \mathrm{~m}$ for the 
element minus the bonding length of a steel reinforcement within the grouted sleeves in the lower element). All lengths considered a concrete cover of $25 \mathrm{~mm}$.

To the design and conception of the models the following aspects were considered:

- The connection device used, corresponding to the bar with a $25 \mathrm{~mm}$ diameter, had a total length of $370 \mathrm{~mm}$ and a maximum internal diameter of $44 \mathrm{~mm}$. This large opening allowed the adjustment in the assembly of the concrete elements. However, they were interfered in the concrete cover of the main bars (the bars inside the sleeves had a concrete cover that considered the stirrups concrete cover that surrounds the sleeves and sleeves' diameter, as illustrated in Figure 9);

- From studies of connections with steel devices, further detailed in Bachega [10], it is possible to observe that it is common to use a concentration of stirrups over the sleeves in the design of this kind of connection. As the connection corresponds to a discontinuity region of the element, when there is the confinement in this region with stirrups, the connection performance allows that the reinforcement achieves the steel yielding, ensuring the structural safety and making possible the structural design in the domain 2 of deformation.

- In this study is also given concerning the assembly with the purpose to represent a real column. Thus, was needed to predict a connection also be capable to guarantee the balance, plumb and safety before the grouting of connection.
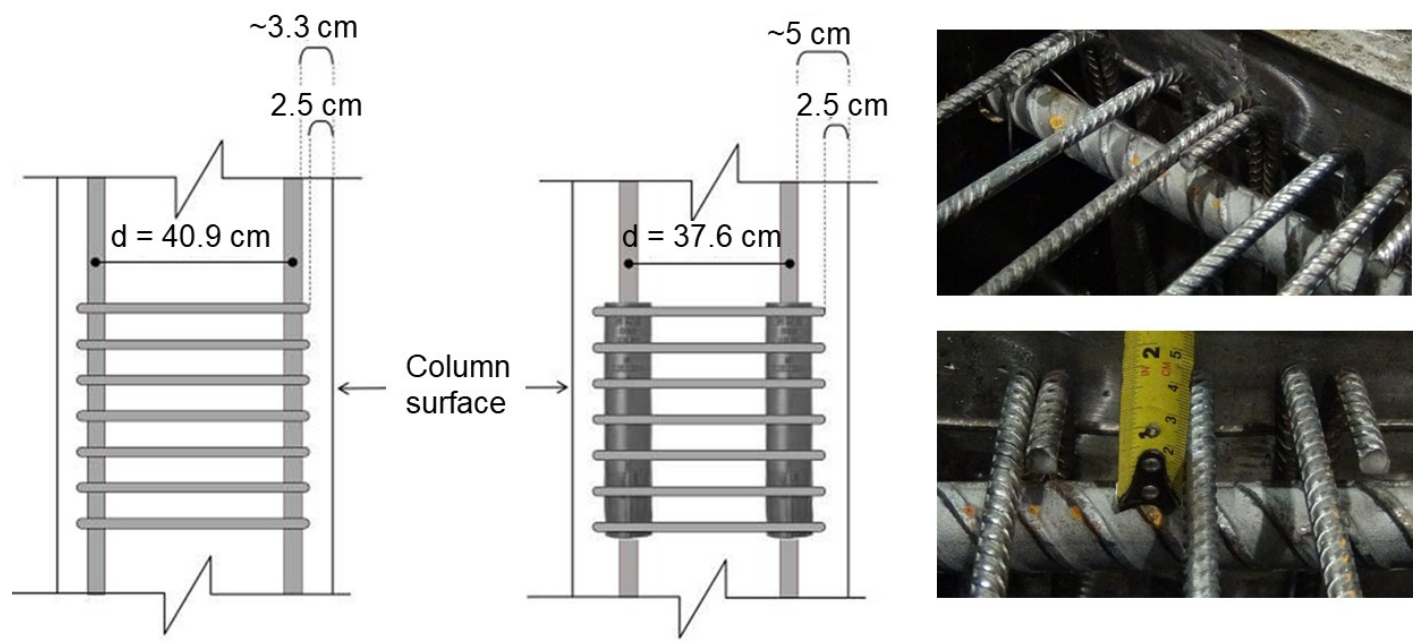

Figure 9. Change of the concrete cover and the effective height in the cross-section, indicating spaces between stirrups and the longitudinal reinforcements [10].

\subsection{Details of test specimens}

The assembly of rebar and the embedment of sleeves at the end of the test specimens are illustrated in Figure 10. The fitting of the rebar within the steel sleeves was simple to perform by just pressing it against the rebar until the limiter to position it. A threaded rubber seal was used at one end of the sleeve to avoid the penetration of cement neat into the device. Before to place the rebar within the metallic mold, the metallic sleeves were fixed on a positioning jig, providing accuracy during the vertical assembly between the lower rebar within the upper metallic sleeves. After the sleeves were fixed onto the wooden jig, transversal stirrups were fixed surrounding the metallic sleeves. Four threaded bars were used to assure the temporary fixing between the lower and upper parts of the column specimen.

The monolithic models were cast at the factory and lifted after curing. Differently from M models, L models were assembled at the factory and needed other phases after the lifting. The lower unit was temporarily placed and plumbed in a pocket foundation. The upper unit was placed over the lower unit to verify if the length of the anchor bolts and the projecting bars were correct. After this verification, steel support plates and other needed devices (such as springs and sealing caps with the purpose to avoid the filling of the sleeve by the joint grout) were used to assemble the upper element. 

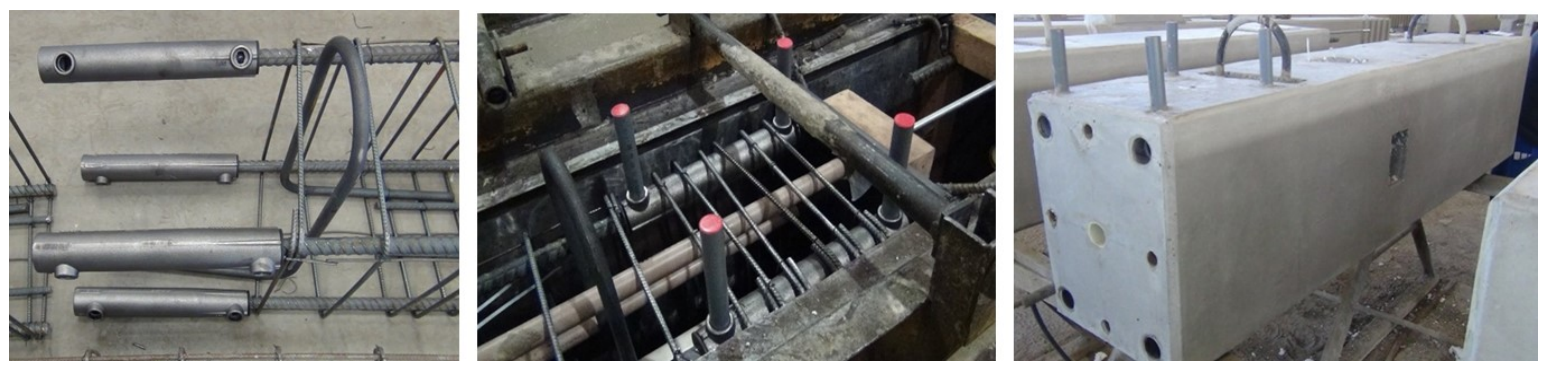

Figure 10. Fabrication of the models [10].

Among possible grouting methods for filling the steel sleeves, the manual filling method by suction pump was adopted. In this method, it is necessary to fill the joints with mortar before the assembly of the upper element. The compressive strength of this mortar should be equal to, or even greater than the lower compressive strength of the connected elements, to maintain the continuity of the concrete elements.

The same grout that filled the steel sleeves was used as the mortar, adding less water to the mixture $(1,500 \mathrm{ml})$ so that the mortar would be more cohesive and moldable. The compressive strength of the grout at 28 days was $70 \mathrm{MPa}$. Then, the mortar was placed on the lower element and the upper element was fitted. The anchor bolts were screwed, and the plumb of the element was adjusted. Three hours after making the mortar (enough time for the grouted joints to reach sufficient strength) the sleeves were grouted. The process started with the cleanness of the sleeves inserting water through the upper opening with the same hand pump employed to grout the joint. Rubber seals were placed into the sleeves' holes to prevent waste and also to make the grouting process cleaner. The grout was made with the same mixture used in the mortar. However, 2,100 $\mathrm{ml}$ of water (instead of 1,500 ml) was added to produce a grout with greater fluidity.

After this process, to measure the grout workability, the slump flow test was carried out, resulting in a slump of $16.5 \mathrm{~cm}$. According to the manufacturer specifications, the grout slump should be between $15.5 \mathrm{~cm}$ and $23.5 \mathrm{~cm}$. Thus, the measured value was close to the lower limit. This occurred due to the lower ambient temperature, around $19^{\circ} \mathrm{C}$. With the acceptance of the slump test, cylindrical and cubic specimens were made to verify the compressive strength. Then, the grouting was carried out with a manual pump by filling the sleeves from the upper one to the lower one to avoid the appearance of air bubbles. Grouting was completed when the indicator placed in the upper hole moved to its maximum limit. To fill the eight metallic sleeves, one bag of the grout mixture was enough (four for each model).

After assembly, the M and L models were transported to the NETPre laboratory to be tested. Thus, according to Figure 11, the assembly sequence was: 1 Fixation of the lower element; 2 Placing the mortar of the joint; 3 Guaranteeing the plumbs of the upper element; 4 Tightening the anchor bolts of the assembly connection (temporary stability); 5 Grouting of steel sleeves.
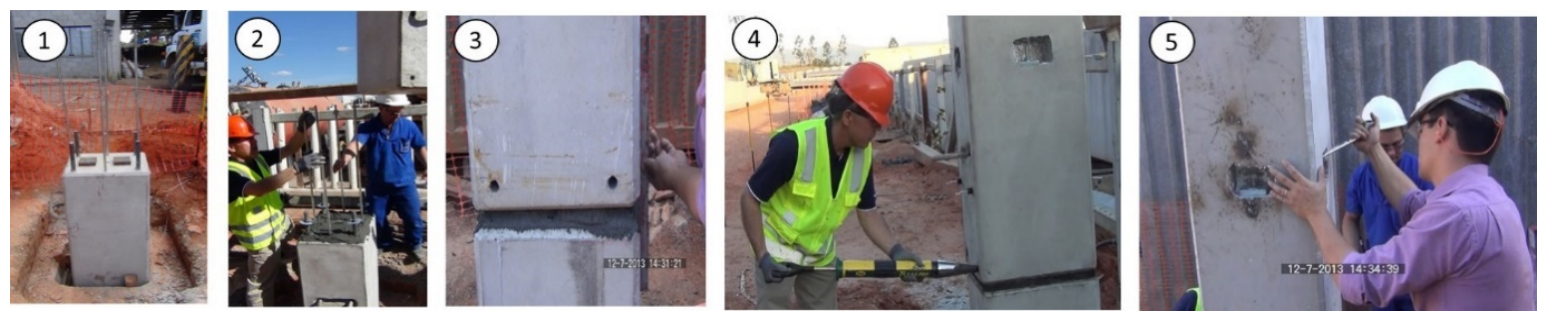

Figure 11. Assembly of the models with connections (L) [10].

\subsection{Test setup}

To measure the moment-rotation relationship within a consistent range of accuracy, bending tests were carried out by applying static concentrated loads at two points according to the test setup shown in Figure 12. 


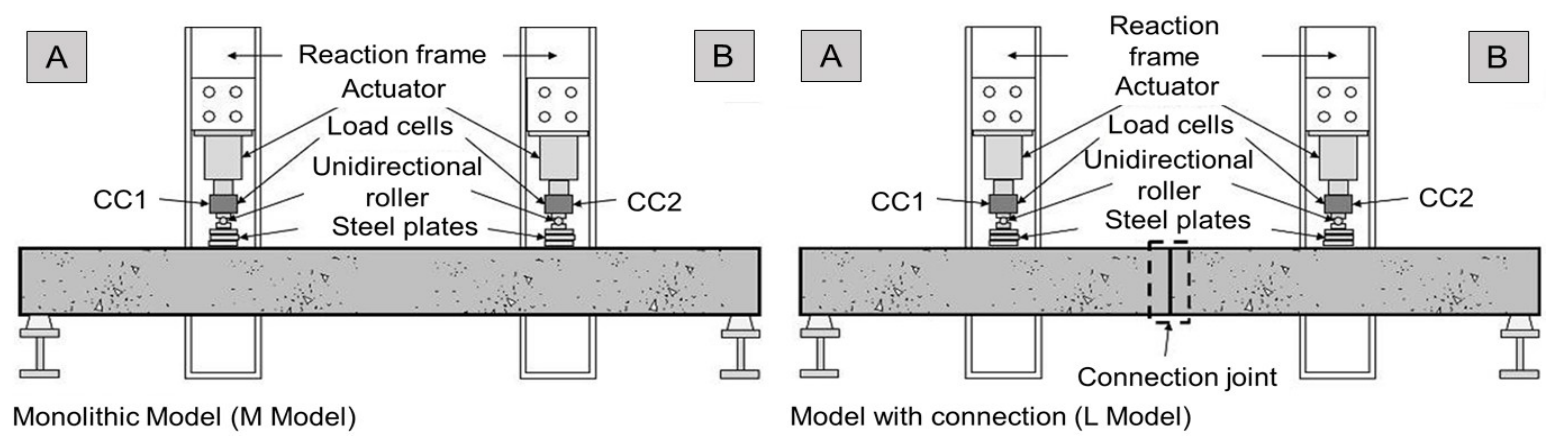

Figure 12. Bending tests carried out in [10].

As aforesaid, this test setup represents an approximation of the column behavior of an industrial building, with the column base embedded in the foundation and a free top or with simple roofs. This configuration usually causes large bending moments at the base of the column and small normal forces, which can still be compression or tension. The test simulates an unfavorable situation for the design of elements subjected to bending.

Hydraulic actuators with the loading capacity of $500 \mathrm{kN}$ were used for continuous application of load (monotonic test). Load cells (LC) were used to measure the applied force, and under the load cell, unidirectional roller supports were used to allow the movement of the models without possible damage. The rectangular metal plates were placed under the roller supports to ensure full transfer of load from the actuator to the concrete.

The models' supports were composed of a Steel "I" profile under a trapezoidal wooden profile (with a rubber tape fixed to the upper face).

\subsection{Experimental instrumentation}

The instrumentation is shown in Figure 13. Ten linear displacement transducers (TD) were used to measure displacements: 08 in the vertical direction ( 02 in the supports, 02 in the position of force application and 04 in the central region) and 02 in the horizontal direction (for calculation of the rotation in the central region, TD9 (top) and TD10 (bottom), see Figure 13), positioned as far as possible from each other.

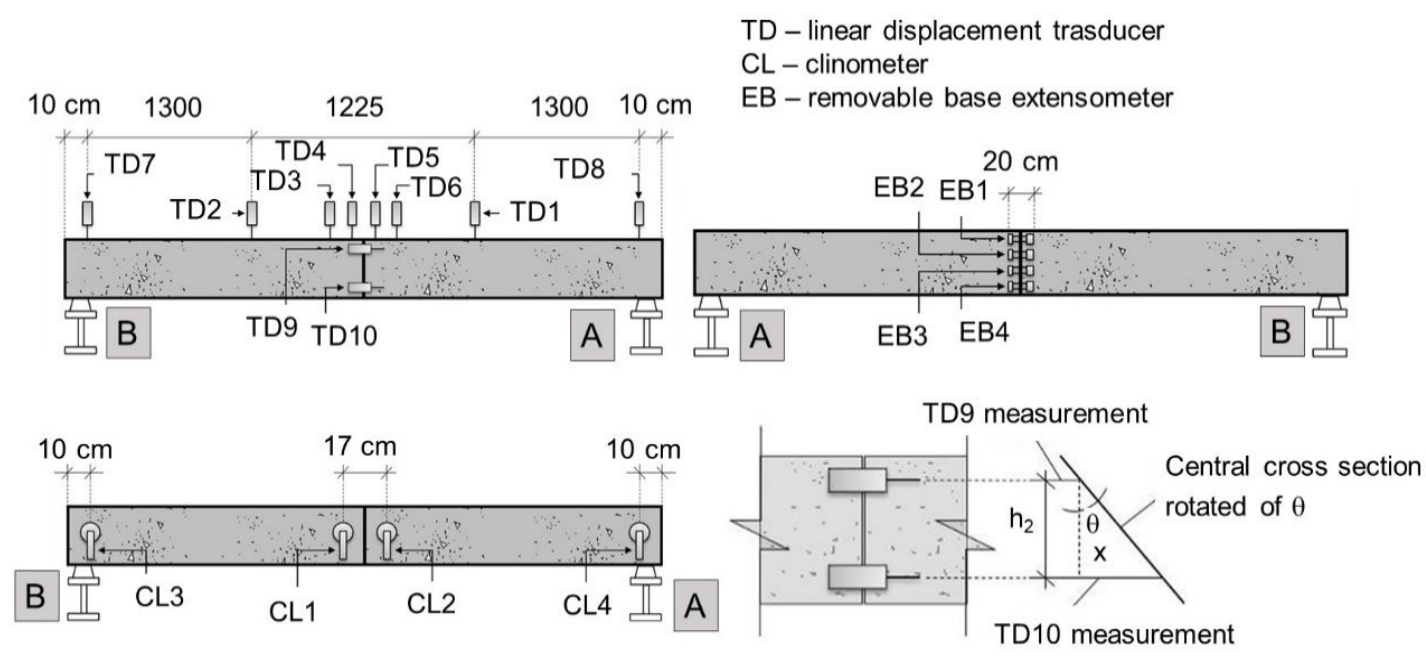

Figure 13. Layout for the test instrumentation in [10].

Rotations in supports and the central region of the models were measured using clinometers (CL). Two (02) clinometers were positioned towards the central transducers, spaced $170 \mathrm{~mm}$ apart and two (02) clinometers at the extreme edges, one on each support, positioned $10 \mathrm{~cm}$ from the end. Four (04) removable base extensometers (EB) were also used to obtain the concrete deformation and the average plane of deformation in the central region cross- 
section to calculate the neutral line. The base length of the extensometer was $200 \mathrm{~mm}$ and an average crack opening was measured along it. These instruments were removed from the models before the end of the test to avoid damage to them. The tests are illustrated in Figure 14.
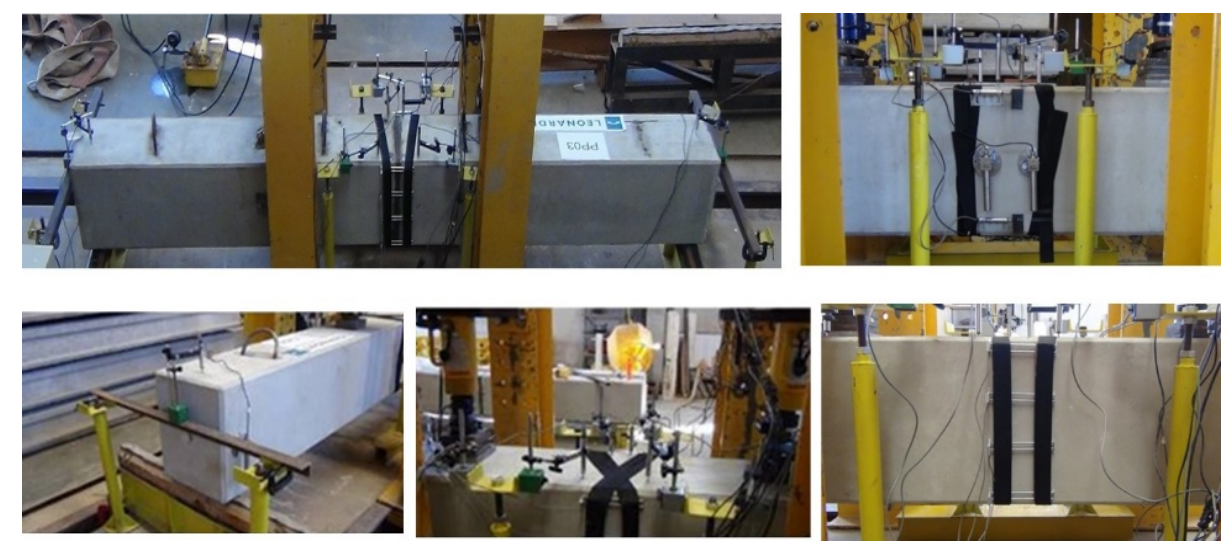

Figure 14. Models instrumentation [10].

\subsection{Mechanical properties of materials}

The compressive strength of concrete and grout was determined in cylindrical specimens with the dimensions of $100 \times 200 \mathrm{~mm}$ for the concrete and $50 \times 100 \mathrm{~mm}$ for the grout. The specimens were molded according to ABNT NBR 5738:2015 [14] and were tested according to ABNT NBR 5739:2007 [15] and according to ABNT NBR 7215:1996 [16], while considering concrete and grout respectively. Cubic grout specimens with $5 \mathrm{~cm}$ edges also were tested to determine the compressive strength. Thus, the average compressive strength of concrete (51.80 MPa) was determined while considering the average value of seven specimens, and the average compressive strength of grout (92.79 MPa) was calculated while considering the average value of three cylindrical specimens. (see Table 1).

The diametrical compression tests were carried out to determine the concrete tensile strength according to ABNT NBR 7222:2010 [17], which allowed the obtaining of the average value of $f_{c t, m e d}=3.724 \mathrm{MPa}$ (Table 2). The initial elasticity modulus $\left(\mathrm{E}_{\mathrm{ci}}\right)$ was determined using concrete cylindrical specimens according to ABNT NBR 8522:2008 [18]. The average value of initial elasticity modulus $\left(\mathrm{E}_{\mathrm{ci}, \mathrm{med}}=44,959\right)$ was obtained from the average value of three specimens with the stress of $\sigma_{\mathrm{n}}=13 \mathrm{MPa}$. So, the average of secant elasticity modulus according to ABNT NBR 6118:2014 [19] was $\mathrm{E}_{\mathrm{cs}, \mathrm{med}}=41,853 \mathrm{MPa}$. In all the tested models, steel class CA-50 was used for the main reinforcements and stirrups, with the mean yield limit being $\mathrm{f}_{\mathrm{yk}}=600 \mathrm{MPa}$ (value provided by the manufacturer) and the elasticity modulus of $\mathrm{E}_{\mathrm{s}}=205 \mathrm{GPa}$ (Table 3).

Table 1. Compressive strength of concrete and grout [9].

\begin{tabular}{|c|c|c|c|c|c|c|}
\hline Concrete & $f_{c}\left(N / m^{2}\right)$ & $f_{c, \text { med }}\left(N / \mathbf{m m}^{2}\right)$ & Grout & & $\mathbf{f}_{\mathrm{c}}\left(\mathrm{N} / \mathbf{m m}^{2}\right)$ & $f_{c, \text { med }}\left(N / \mathbf{m m}^{2}\right)$ \\
\hline $\mathrm{CP} 1$ & 51.48 & \multirow{7}{*}{51.80} & \multirow{3}{*}{ cylindrical } & $\mathrm{CP} 1$ & 104.44 & \multirow{3}{*}{92.79} \\
\hline $\mathrm{CP} 2$ & 51.34 & & & $\mathrm{CP} 2$ & 89.20 & \\
\hline $\mathrm{CP} 3$ & 53.91 & & & $\mathrm{CP} 3$ & 84.72 & \\
\hline $\mathrm{CP} 4$ & 52.76 & & \multirow{3}{*}{ cubic } & $\mathrm{CP} 4$ & 116.43 & \multirow{3}{*}{95.39} \\
\hline $\mathrm{CP} 5$ & 49.16 & & & CP5 & 75.58 & \\
\hline CP6 & $38.41^{*}$ & & & CP6 & 94.15 & \\
\hline $\mathrm{CP} 7$ & 52.12 & & & & & \\
\hline
\end{tabular}

*value disregarded in the calculation of average value 
Table 2. Tensile strength of concrete $f_{c t}$ from the diametral compression test $\left(f_{c t, s p}\right)$ according to ABNT NBR $7215: 1996$ [16].

\begin{tabular}{|c|c|c|c|c|c|c|}
\hline Specimen & d (mm) & I (mm) & $F(N)$ & $f_{c t, s p}\left(N / m^{2}\right)$ & $f_{c t}\left(N / m^{2}\right)$ & $\mathbf{f}_{\mathrm{ct}, \mathrm{med}}\left(\mathrm{N} / \mathbf{m m}^{2}\right)$ \\
\hline $\mathrm{CP} 1$ & 100 & 200 & 106,300 & 3.384 & 3.045 & \multirow{3}{*}{3.724} \\
\hline $\mathrm{CP} 2$ & 100 & 200 & 141,800 & 4.514 & 4.062 & \\
\hline $\mathrm{CP} 3$ & 100 & 200 & 141,900 & 4.517 & 4.065 & \\
\hline
\end{tabular}

Table 3. Summary of the concrete characteristics used in the tested models.

\begin{tabular}{|c|c|c|c|c|c|}
\hline $\begin{array}{l}\text { Compression } \mathbf{f}_{\mathbf{c}, \text { med }} \\
\left(\mathbf{N} / \mathbf{m m}^{2}\right)\end{array}$ & $\begin{array}{l}\text { Initial Elasticity } \\
\text { Modulus Eci,med } \\
\quad\left(\mathbf{N} / \mathbf{m m}^{2}\right)\end{array}$ & $\begin{array}{c}\text { Secant } \\
\text { Modulus } \\
\text { Ecs,med. } \\
\left(\mathbf{N} / \mathbf{m m}^{2}\right)\end{array}$ & $\begin{array}{c}\text { Tension (NBR } \\
7222: 2010)[17] \\
\text { fct,med }\left(\mathrm{N} / \mathrm{mm}^{2}\right)\end{array}$ & $\begin{array}{l}\text { Cracking Bending } \\
\text { Moment } M_{r}(k N \cdot m)\end{array}$ & $\begin{array}{l}\text { Moment of Inertia } \\
\text { (Stage II) III }\left(\mathrm{mm}^{4}\right)\end{array}$ \\
\hline 51.80 & 44,959 & 41,853 & 3.724 & 53.0 & $67,781.77 \cdot 10^{-4}$ \\
\hline
\end{tabular}

\section{EXPERIMENTAL RESULTS}

Bachega [10] presents the strain measurements by observing tensile strain on the bottom fibers and compressive strain on the top fibers (Figure 15). Moreover, it was observed that the models with connections presented initial strain values higher than the monolithic models. Thus, it was possible to trace the average strain plane of each model while considering the measurement variations of the extensometers until the value of $160 \mathrm{kN}$ at both points of the loading application.

The positioning of the neutral line is evident when the cracking pattern of the models is analyzed, so that in the monolithic models the cracking spread out from the cross-section of the middle of the span, while in the models with connections the cracking started in intermediate sections between the middle of the span and the load application point (Figure 15).

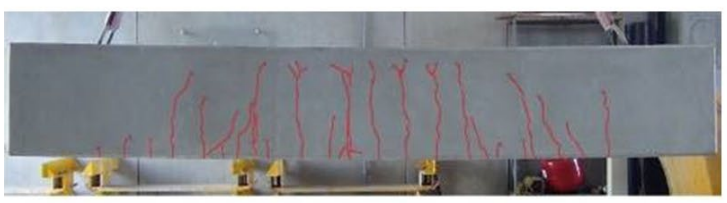

Monolithic Model

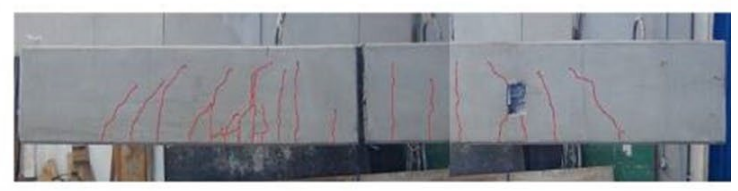

Model with connection

Figure 15. Cracking pattern for the models obtained in [10].

Figure 15 shows the applied force versus vertical displacement curves (deflection) for the four models tested, and it is possible to observe that the four models showed very similar behavior, and even after cracking, all models presented a very similar stiffness gradient and a significant reduction in the vicinity of the applied force of $180 \mathrm{kN}$, showing the reinforcement yielding. Figure 16 shows the applied force versus rotation curves on the supports for the four models, making it possible to observe a very similar behavior between the four models, showing that all of them presented a variation of the effective stiffness very similar for the different stages of the applied load.

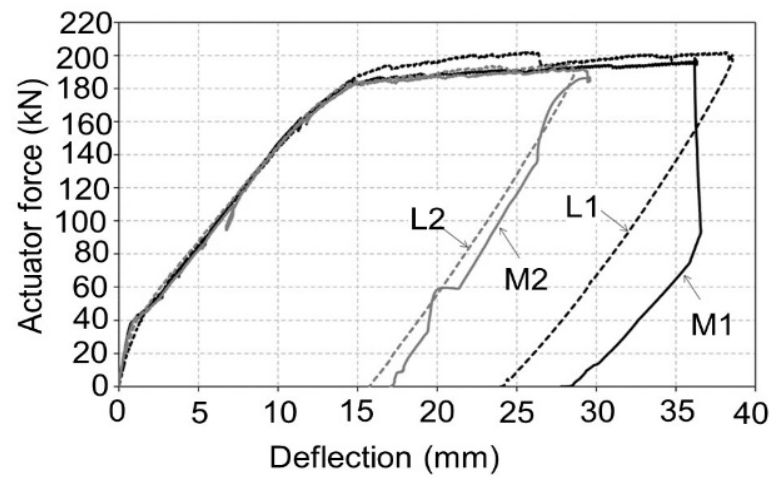

Figure 16. Actuator force vs deflection curves obtained in [10]. 


\section{EQUIVALENT STIFFNESS OF THE PRECAST COLUMNS}

The equivalent stiffness of precast columns with grouted splice sleeves was confronted against the actual relative stiffness obtained for the monolithic elements, taking into account the force-deflection relationship along the columns as well as the force-rotation relationship at the supports, as shown in Figures 16 and 17, respectively. It was possible to observe that after the crack begins ( $\mathrm{P}=40 \mathrm{kN}$ at each point of load application) until the limit of elastic behaviour, prior the steel bars reach their yield strength (around $\mathrm{P}=180 \mathrm{kN}$ ), the relative stiffness along the structural elements was very similar for all the test results.

Based on Figure 17a, while considering the beginning of the yield strength of the steel bars (for the applied P force) and the rotation $\theta$ at the support considered as the average from the measurements taken from clinometers CL3 and CL4, positioned at the supports, it was possible to determine $\mathrm{EI}_{\mathrm{ef}}$ (effective stiffness) according to Equation 11, as follows:

$E I_{\text {ef }}=\frac{P \cdot a \cdot\left(\frac{L}{2}\right) \cdot\left(1-\frac{a}{L}\right)}{\theta_{\text {support }}}$

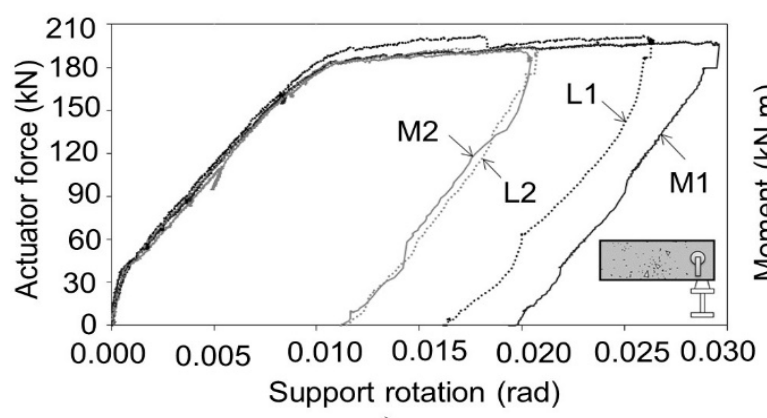

a)

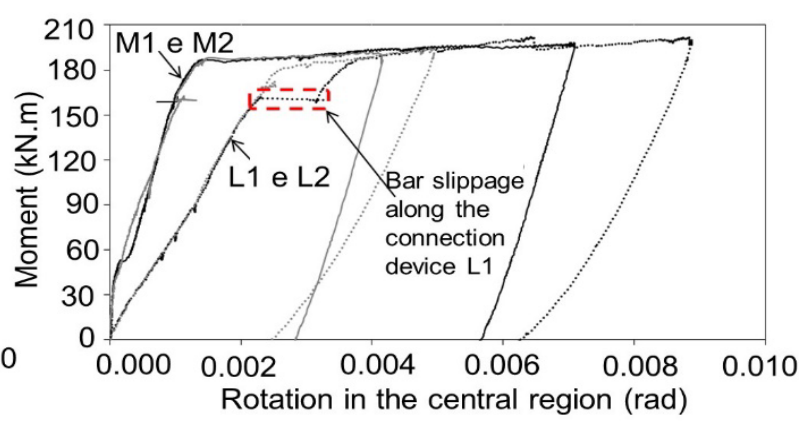

b)

Figure 17. a) Curves force $x$ rotation at support measured by clinometers; $b$ ) Curves moment $x$ rotation at the center [10].

Table 4 shows the values of the effective stiffness coefficient $(E I)_{\text {ef }}$ corresponding to the secant stiffness obtained at the beginning of the yielding in the experimental curves illustrated in Figure 17b). The cracking moment $\mathrm{M}_{\mathrm{r}}$ obtained for $\mathrm{f}_{\mathrm{ct}} \leq 1.2 \cdot \mathrm{f}_{\mathrm{ctk}, \text { inf }}=1.2 \cdot 0.7 \cdot \mathrm{f}_{\mathrm{ctm}}=0.8 \cdot \mathrm{f}_{\mathrm{ctm}}\left(\mathrm{f}_{\mathrm{ctm}}=3.74 \mathrm{MPa}\right)$ was of $\mathrm{M}_{\mathrm{r}}=53 \mathrm{kN} \cdot \mathrm{m}$. This value is compatible with the moment reached for an applied force $\mathrm{P}_{\mathrm{r}}=40.8 \mathrm{kN}$.

Table 4. Coefficient of effective stiffness (EI) $)_{\text {ef }}$ for the tested models.

\begin{tabular}{|c|c|c|c|c|c|c|c|}
\hline Model & $P(k N)$ & $\mathbf{L}(\mathbf{m m})$ & a (mm) & $\begin{array}{c}\text { (EI) })_{\text {ef }} \text { Deflection } \\
\left(\mathrm{kN} \cdot \mathrm{m}^{2}\right)\end{array}$ & $\begin{array}{c}\text { (EI)ef Rotation } \\
\left(\mathbf{k N} \cdot \mathbf{m}^{2}\right)\end{array}$ & $\begin{array}{c}(\mathrm{EI})_{\text {ef }} \text { Average } \\
\left(\mathrm{kN} \cdot \mathrm{m}^{2}\right)\end{array}$ & $\begin{array}{r}\mathbf{E}_{\text {cs,med }} \cdot \mathbf{I}_{2} \\
\left(\mathbf{k N} \cdot \mathbf{m}^{2}\right)\end{array}$ \\
\hline M1 & 180.8 & 3783 & 1283 & 28,916 & 28,073 & \multirow{2}{*}{28,471} & \multirow{2}{*}{28,400} \\
\hline M2 & 179.0 & 3797 & 1298 & 28,808 & 28,088 & & \\
\hline L1 & 178.0 & 3827 & 1304 & 32,554 & 30,613 & \multirow{2}{*}{30,904} & \multirow{2}{*}{28,400} \\
\hline L2 & 177.1 & 3820 & 1310 & 30,903 & 29,546 & & \\
\hline
\end{tabular}

All models reached $\mathrm{EI}_{2}$ (stiffness of the cracked section) around $180 \mathrm{kN}$ referring to the acting moment at the beginning of the reinforcement yielding $\mathrm{M}_{\mathrm{a}}=234 \mathrm{kN} \cdot \mathrm{m}$. The $\mathrm{EI}_{2}$ value was obtained as follows: $E_{c s} I_{2}=41,850 \cdot 6.78 \cdot 10^{8}=2.84 \cdot 10^{13} \mathrm{~N} \cdot \mathrm{mm}^{2}=28,400 \mathrm{kN} \cdot \mathrm{m}^{2}$

\section{SECANT STIFFNESS OF THE COLUMN-TO-COLUMN CONNECTION}

To evaluate the secant stiffness $\left(\mathrm{R}_{\mathrm{sec}}\right)$ performance of the connection, defined by the secant of the moment-rotation curve (relative rotation between the column elements), the secant stiffness $\left(\mathrm{R}_{\mathrm{sec}}\right)$ was determined by Equation 1 , as shown in Figure 4. Therefore, the limit-moment that defines the beginning of the yielding, given by Equation 4, was 
$\mathrm{M}_{\mathrm{y}, \mathrm{lim}}=231.94 \mathrm{kN} \cdot \mathrm{m}$, corresponding to the rotation of the models shown in Table 5. It was observed that the central region of the model with connection presented a secant stiffness $\left(R_{\sec }=77,785 \mathrm{kN} \cdot \mathrm{m} / \mathrm{rad}\right) 58.3 \%$ the secant stiffness $\left(\mathrm{R}_{\mathrm{sec}}=186,497 \mathrm{kN} \cdot \mathrm{m} / \mathrm{rad}\right)$ obtained while considering the corresponding rotation of the monolithic model. In fact, it was expected that there would be a loss of stiffness in the connection region. In this case, a dry joint was made before filling the grout in the mechanical sleeves.

Table 5. Value of secant stiffness $R_{s e c}$ for the central region.

\begin{tabular}{|c|c|c|c|c|}
\hline Model & $\theta_{y, l i m} *(\mathbf{r a d})$ & $\theta_{y, \text { med }}(\mathbf{r a d})$ & $R_{s e c}(\mathbf{k N} \cdot \mathbf{m} / \mathbf{r a d})$ & Dif. (\%) \\
\hline M1 & $1.245 \mathrm{E}-03$ & \multirow{2}{*}{$1.244 \mathrm{E}-03$} & \multirow{2}{*}{186,497} & \multirow{2}{*}{---} \\
\hline M2 & $1.242 \mathrm{E}-03$ & & & \\
\hline L1 & $3.480 \mathrm{E}-03$ & \multirow{2}{*}{$2.982 \mathrm{E}-03$} & \multirow{2}{*}{77,785} & \multirow{2}{*}{-58.3} \\
\hline L2 & $2.484 \mathrm{E}-03$ & & & \\
\hline
\end{tabular}

*rotation obtained as defined in Figure 13

Based on the moment-rotation relationship obtained experimentally while considering only the local section of the columnto-column connection, the comparison of the secant stiffness obtained for the two types of models ( $\mathrm{L}$ and $\mathrm{M}$ model) showed a discontinuity located in the joint. In this case, if only the stiffness of the connection section was considered, the connection could be considered as semirigid. However, the effective region of the connection, in this case, is much larger, because it includes the ends of each segment, which correspond to the sections with more stirrups, with additional threaded bars used for assembly and also with an increase in the steel area in the region of the mechanical sleeves (an increase of around 30\%), which provided greater confinement of the longitudinal reinforcements, with better crack control.

Therefore, it is possible to observe that there was a stiffness compensation in the segmented model, where the loss of rotational stiffness within the column-to-column joint was compensated by the increase of the relative stiffness within the connection zone (wherein there is a concentration of stirrups surrounding the steel sleeves). In other words, it is believed that the single crack opening at the joint between the precast units was equivalent to the sum of cracks within the corresponding region in the cracked monolithic models.

Considering the experimental secant stiffness $\mathrm{R}_{\mathrm{SEC}}=77,785 \mathrm{kN} \cdot \mathrm{m} / \mathrm{rad}$, while taking into account the use of grout with a resistance much higher than the concrete strength of the precast models, and adopting $\mathrm{k}=1.0$, it was possible to obtain an effective deformation length corresponding to $L_{e d}=20 \varnothing_{b}$, as follows: $L_{e d}=k \frac{E_{s} A_{s} d^{2}}{R_{\text {sec }}}=(1.0) \cdot \frac{205 \cdot 982 \cdot 436.5^{2}}{77,785,000} \cong 20 \varnothing_{b}$, where $\varnothing_{b}=25 \mathrm{~mm} ; A_{s}=982 \mathrm{~mm}^{2} ; E_{s}=205 \mathrm{kN} / \mathrm{mm}^{2} ; d=437.5 \mathrm{~mm}$

Therefore, the secant stiffness of the studied connection can be represented by the following expression: $R_{s e c}=\frac{E_{s} A_{s} d^{2}}{20 \varnothing_{b}}$

Based on the values of $\mathrm{M}_{\mathrm{y}, \text { lim }}$ and $\theta_{\mathrm{y}, \text { lim, }}$, using Equations 1 to 9 , it was possible to predict a trilinear diagram to represent the connection behavior, as shown in Figure 18, considering the effective deformation length of $L_{e d}=20 \varnothing_{b}$.

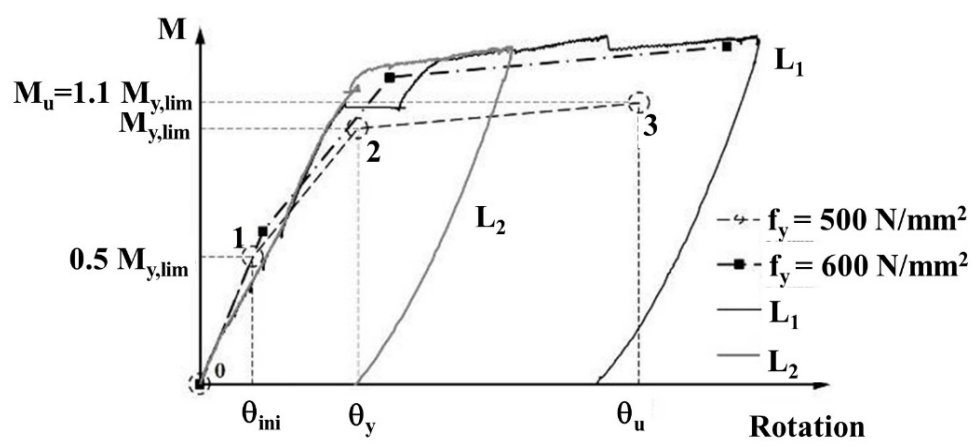

Figure 18. Trilinear diagram for the connection characterization [10]. 


\section{CONCLUSIONS}

Based on the analysis and interpretation of the experimental results, it has been evidenced that the precast members with grouted splice sleeve connections presented relative stiffness that was equivalent to the monolithic members. Therefore, precast columns with this type of connection can be considered in design as a continuous column.

Applying the equations for the secant stiffness and the fixity factor, it was possible to validate a design procedure using a trilinear diagram to predict the structural performance of the column-to-column connection, wherein the connectors were classified as rigid.

Furthermore, the higher concentration of stirrups surrounding the splice sleeves within the connection zone, with the addition of longitudinal reinforcement (from threaded bars used in the assembly and the steel area in the sleeve region) in the segmented models promoted higher confinement for the longitudinal reinforcements and, consequently, better crack control within the connection zone when comparing with the monolithic elements.

Therefore, it is possible to conclude that there was a compensation of the relative stiffness along the spliced member, wherein the loss of rotational stiffness located at the column-to-column joint was compensated by a higher relative stiffness in the connection region.

The authors highlight that the bending test setup used by Bachega [10] was first meant to evaluate a precast column in a single-story building, taking into account a critical design situation under lateral loads. Therefore, carrying out new bending tests combining compressive axial forces, to simulate the load combination in multi-story buildings, can lead to a situation far less critical, wherein the relative stiffness of the precast columns are similar to the behaviour the monolithic ones.

Although the results were satisfactory for the effective behaviour of the connection, it is noteworthy that the connection performance can be improved by enhancing some of the connection details. For instance: improving the confinement within the connection region by adding more stirrups; improving the method of column-to-column joint filling by exploring other alternatives besides the use of dry joints; and improving the distribution of the steel area across the cross-section.

\section{ACKNOWLEDGEMENTS}

The authors acknowledge UFSCar and NETPre for providing laboratory facilities, ABCIC for Institutional support, Leonardi Industrialized Construction Company for the donation of precast elements, and Splice-Sleeve Japan for financial assistance.

\section{REFERENCES}

[1] Associação Brasileira de Normas Técnicas, Projeto e Execução de Estruturas de Concreto Pré-moldado, ABNT NBR 9062:2017, 2017.

[2] A. Einea, T. Yamane, and M. K. Tadros, "“Grout-filled sleeve splices for precast concrete Construction”, Prec. Prestr. Concr. Inst. J., vol. 40, no. 1, pp. 82-93, 1995.

[3] B. Ahn, H. Kim, and B. Park, "Confining effect of mortar grouted splice sleeve on reinforcing bar," J. Korea Concr. Inst, vol. 15, no. 1, pp. 102-109, 2003.

[4] L. J. Hua, A. B. A. Rahman, I. S. Ibrahim, and Z. A. Hamid, "Feasibility study of grouted splice connector under tensile load," Constr. Build. Mater., vol. 50, pp. 530-539, 2014.

[5] A. Belleri and P. Riva, "Seismic performance and retrofit of precast concrete grouted sleeve connections", Prec. Prestr. Concr. Inst. J., vol. 57, no. 1, pp. 97-109, 2012.

[6] M. J. Ameli, D. N. Brown, J. E. Parks, and C. P. Pantelides, "Seismic column-to-footing connections using grouted splice sleeves," ACI Struct. J., vol. 87, no. 113-S, pp. 1021-1030, 2016.

[7] J. Kinnunen, "ETA tests and design of HPKM Column Shoe Connections," Proc. Eng., vol. 172, pp. 521-528, Feb 2017.

[8] European Commitiee for Standardization. Eurocode 2: Design of Concrete Structures. Part 1-1: General Rules and Rules for Buildings, EN 1992-1-1:2004, 2004.

[9] N. Tullini and F. Minghini, "Grouted sleeve connections used in precast reinforced concrete construction - Experimental investigation of a column-to-column joint," Eng. Struct., vol. 127, pp. 784-803, 2016.

[10] L. A. Bachega, "Equivalência monolítica em pilares com ligações por meio de luvas metálicas grauteadas", PhD dissertation, Univ. Fed. de São Carlos, 2016.

[11] Splice Sleeve Japan, Engineering Datasheet, Tokyo, Japan: Splice Sleeve Japan, 1990.

[12] American Concrete Institute, Guide to Emulating Cast-in-place Detailing for Seismic Design of Precast Concrete Structures, ACI 550.1R-09, 2012. 
[13] M. A. Ferreira, K. S. Elliott, and S. Hasan, State-of-Art Research Report: Precast Concrete Framed Structures with Semi-rigid Connections, Nottingham, UK: School of Civil Engineering, University of Nottingham, 2010

[14] Associação Brasileira de Normas Técnicas, Concreto - Procedimento para Moldagem e Cura de Corpos de Prova, ABNT NBR 5738:2015, 2015.

[15]Associação Brasileira de Normas Técnicas, Concreto - Ensaio de Compressão de Corpos de Prova Cilindricos - Método de Ensaio, ABNT NBR 5739:2007, 2007.

[16] Associação Brasileira de Normas Técnicas, Cimento Portland: Determinação da Resistência à Compressão, ABNT NBR 7215:1996, 1996.

[17]Associação Brasileira de Normas Técnicas, Concreto e Argamassa: Determinação da Resistência à Tração por Compressão Diametral de Corpos de Prova Cilíndricos, ABNT NBR 7222:2010, 2010.

[18]Associação Brasileira de Normas Técnicas, Concreto - Determinação dos Módulos Estáticos de Elasticidade e Deformação, ABNT NBR 8522:2008, 2008.

[19]Associação Brasileira de Normas Técnicas, Projeto de Estruturas de Concreto: Procedimentos, ABNT NBR 6118:2014, 2014.

Author contributions: MAF: supervision, writing conceptualization, funding acquisition, supervision, writing and formal analysis; LAB: conceptualization, experimental analysis, methodology and experimental tests; BC: data curation, experimental tests, methodology, conceptualization, writing and text formatting.

Editors: José Marcio Calixto, José Luiz Antunes de Oliveira e Sousa, Guilherme Aris Parsekian. 